6. Пикок А. От науки к Богу: Новые грани восприятия религии. Пер. с англ. К. Савельева. - М.: ФАИР-ПРЕСС, 2002. - 304 с.

7. Суинберн Р. Есть ли Бог? Пер. с англ. - М., Библейскобогословский институт св. апостола Андрея, 2006. - 120 с.

8. Суинбёрн Р. Существование Бога / Российская акад. наук, Ин-т философиии, О-во христианских философов; пер. с англ. М. О. Кедровой. - М.: Языки славянской культуры, 2014. - 462 с.
9. Richard Swinburne. Faith and Reason. - Oxford: Clarendon Press, 1981. - $288 \mathrm{p}$.

10. Richard Swinburne. The Coherence of Theism. - Oxford: Clarendon Press, 1977. $-302 p$

Надійшла до редколегії 07.04.19

I. P. Gudyma

\title{
PROBABILISTIC METHOD OF RICHARD SWINBURNE AS A MEANS OF CONSTRUCTING
} A NEW THEISTIC COSMOLOGY

In the article a comprehensive study of the probabilistic method of the famous British theologian and philosopher Richard Swinburne. This approach serves as a means of constructing a new theistic cosmology.

Richard Swinburne's philosophical and theological project is ambitious and significant. He prefers to combine the truths of faith and the achievements of modern science. However, this should be under the auspices of the religious worldview. This combination is carried out by the author from the standpoint of probabilism. It relies on the selection of inductive evidence of the existence of God and ultimately must demonstrate the proper probability of a central position in the religious worldview - "God exists". Such a combination is, according to the author, the living and active soul of his own "hypothesis of theism". This hypothesis is intended to explain the emergence of the universe, the causes of its occurrence, the existence and functioning of its permanent laws, its orientation to the emergence of animals and the appearance of man.

The author widely uses the inductive proof of the existence of God. But he also does not avoid deduction. He deduces the main attributes of God through deduction, interprets the "God-world" relation, examines the essence of God's providential care of the world, together with ethics, gives his vision of the theodicy. The construction of a new theistic cosmology is realized mainly within the limits and means of the apologetics of Swinburne. In this system of knowledge, various ways of proving the existence of God are investigated. Subsequently they receive a proper theological assessment. And, then, it's about faith that seeks understanding.

It is shown how the large-scale and ambitious project of constructing a new theology, the author failed to fully realize. The article states that Swinburne prefers to preserve the theoretical orientation of his theorizing, as well as their intellectual respectability and significance. And hence, it significantly degrades its own concept, because it does not fully utilize the theoretical resources of classical theism with its reliance on Revelation.

Keywords: God, universe, faith, science, probability.

И. П. Гудыма

ПРОБАБИЛИСТСКИЙ МЕТОД РИЧАРДА СУИНБЕРНА

КАК СРЕДСТВО ПОСТРОЕНИЯ НОВОЙ ТЕИСТИЧЕСКОЙ КОСМОЛОГИИ

В статье всестороннему изучению подвергается пробабилистский метод известного британского теолога и философа Ричарда Суинберна, который выступает у него средством построения новой теистической космологии. Показывается, почему маситабный и амбициозный проект развития новой теологии, начатый Суинберном, автору не удалось реализовать в полной мере.

В статье доказывается, что Суинберн, предпочитая сохранить сциентическую ориентированность своих теоретизирований, также, как и их интеллектуальную респектабельность и значимость, чего требует от него принадлежность к сообществу англоамериканских интеллектуалов, ощутимо обедняет собственную концепцию, в полной мере не привлекая теоретические ресурсы классического теизма с его опорой на Откровение и при этом делая уступки теизму адаптивному.

Ключевые слова: Бог, вселенная, вера, наука, вероятность.

удк 291.1:159.922

В. М. Калач, аспірант

\section{РЕЛІГІЙНА ІДЕНТИЧНІСТЬ В КОНТЕКСТІ ЕТНОНАЦІОНАЛЬНОГО РОЗВИТКУ УКРАЇНИ}

У статті розелядаються особливості формування релігійної ідентичності в динаміці геополітичних процесів в Украйні, які залежать від історичних умов, особливостей економічного і соціально-політичного устрою, демократичних і культурних традицій суспільства, рівня правового і морального розвитку його членів та амбіцій його лідерів. Доведено, що релігія є вирішальним фактором етнічного буття українців, наголошено на суперечливій ролі християнства в етноідентифікаційних та етноконсолідаційних процесах українства.

Ключові слова: релігійна ідентичність, самоідентифікація, міжрелігійні відносини, етнонаціональна свідомість.

У сучасному глобалізованому світі Україна перебуває в пошуку, з одного боку, втраченої, а з іншого - ще не віднайденої та несформованої спільної національної ідентичності. В ситуації незворотного пришвидшення темпу життя сучасної людини релігійна ідентичність постає важливим фактором самоідентифікації і самовизначення як окремого індивіда, так і цілих соціальних спільнот. Знаходячись на зіткненні різних цивілізаційних систем, наша держава постійно вагається із вектором політично-економічного розвитку.

Проблема релігійної детермінанти в зарубіжній і вітчизняній науковій парадигмі досліджувалася представниками різних наукових дисциплін й теоретикометодологічних підходів. Зокрема, сутність національної і релігійної ідентичності розглядалися в працях А. Арістової, В. Єленського, С. Здіорука, А. Колодного, М. Мариновича, О. Сагана, Т. Воропаєвої, Л. Филипович та інших, які визначали релігію не лише важливим, а й вирішальним фактором етнічного буття українців і акцентували на недвозначній ролі християнства в процесі етнічної ідентифрікації українського суспі- льства. Отже, питання місця та значення релігії у формуванні та трансформації релігійної ідентичності наразі $€$ недостатньо дослідженим, наукові розвідки носять фррагментарний характер й потребують систематизації та фрілософрського осмислення.

Значна активізація світових глобалізаційних процесів диктує умови завершеності державо- та націотворення, що неминуче тягне формування єдиної національної та релігійної ідентичності громадян України. Сьогодні це питання постає надзвичайно актуальним, адже його наукове осмислення виходить із потреб самовизначення України та вибору майбутнього вектору розвитку і становлення. Проблема етнорелігійної самоідентичності загострилася на зламі третього тисячоліття. Цей процес виходить за межі виключно наукової проблематики та набуває загальносуспільного та політичного значення.

Відсутність загальносуспільної єдності та порозуміння щодо основних питань стратегічного поступу України посилює актуальність вивчення проблеми релігійної ідентичності наших співгромадян, адже саме вона $є$ однією 
з першооснов формування загальнонаціональної самоідентифрікації українців. Велика амплітуда розходження в основних питаннях розвитку України між жителями Сходу та Заходу змушує констатувати факт неоднорідності ідентичностей мешканців цих регіонів, знову ж одне із ключових місць у цьому питанні займає релігія.

Важливо, що національно свідомими громадянами можуть бути не тільки представники корінного населення, а й інші національності, що проживають у певній країні. Якраз цей фактор і формує спільну національну ідентичність, в тому числі і на релігійному чи етнічному підґрунті. Національно свідома особа пов'язує себе з певною державою і вбачає в цьому одну із цілей життя. Такі люди не лише цікавляться історією країни, а й беруть учать у її сьогоденні [8, с. 170]. А без спільної національної свідомості та ідентичності нація як така просто немислима.

Вплив міжрелігійних відносин в Україні на економічний та суспільно-політичний розвиток, на її цивілізаційне та геополітичне самовизначення, утвердження єдиного вектору державницької політики визначається широким колом дослідників. Якщо кілька десятиліть тому церква помітно відходила на другий план у суспільнодержавному розвитку нашої країни, то сьогодні вона займає все вагоміше місце [5, с. 280].

Відзначимо позитивний досвід розробки та висвітлення ідентифікаційних та орієнтаційних проблем громадян України в контексті сучасних переплетень різновекторних впливів та світоглядних переконань. Важливо, що досвід вирішення таких проблем не гірший за їх теоретичне обґрунтування. Це стосується законодавчої сорери, вирішення гуманітарних проблем, регулювання міжконфесійних конфліктів, різноманітних соціальних програм та ін. Мультикультурний та поліконфесійний Захід показує приклад утвердження толерантності та співіснування різних релігійних ідентичностей на одній території. Втілення цих цінностей в життя українського суспільства $€$ об'єктом провідних вітчизняних вченихрелігієзнавців [13, с. 91].

Релігія є важливою смислотворчою складовою загальнонаціональної ідентичності. Віра передається людині із покоління в покоління протягом віків, відтак $\epsilon$ константою, що зумовлює світогляд та мислення великих груп населення. Кожна із релігій дає віруючим відповіді на базові питання: "яке моє місце в цьому житті", "хто я". Вона надає почуття спільної ідентичності та вказує напрямок руху. У свою чергу етнічна й релігійна ідентичність тісно переплетені між собою, тому етнорелігійний чинник постійно викликає велику увагу науковців та державних діячів. Не дивно, що багато релігійних груп збігається із межами певного етносу [12, с. 46].

Невипадково релігія стає основою формування новітнього етносу, в тому числі й в Україні. Вона визначає місце окремо взятого народу в загальному Промислі Божому, а також визначає його призначення в цьому світі. Крім того, релігія формує специфічний внутрішній простір етнічного осередку в контексті його спілкування з Богом. А держава навпаки, за своєю суттю $є$ позаетнічною, позанаціональною та, як правило, позарелігійною [11, с. 140]. Відтак, формування національної ідентичності швидше залежить від релігії, ніж від держави.

Релігія відіграє визначальну роль у формуванні етно-національної свідомості особливо в переломні часи, які зараз спостерігаються у багатьох посткомуністичних країнах. В умовах розвалення старих цінностей і вивільнення приглушених різноспрямованих релігійних за- цікавленостей всіх прошарків населення церква постає надійним інтегратором суспільства. Саме вона має відпрацьовані століттями механізми впливу на масову свідомість громадян.

Православна традиція значно вплинула на формування тисячолітньої історії українських земель. Відділити українську націю від християнства сьогодні неможливо. Разом із тим, на початку третього тисячоліття таке стратегічне питання для України, як становлення власної незалежної Церкви, наразі невирішене. Релігійна ідентифікація ще більше укорінюється у власній біполярності. Процес вироблення нової церковної ідеології, яка могла би бути новим стрижнем консолідації нашого суспільства, важливим об'єднавчим та миротворчим фрактором, заходить у безвихідне положення. Загалом, українська нація - немислима без незалежної української Церкви. Цей процес безперспективний поки в Україні провадить свою діяльність Московський патріархат у вигляді УПЦ МП. "Духовна опіка" Росії над Україною занадто затягнулася, це призвело до фоомування глобальної на Сході країни проросійської релігійної орієнтації населення. А чи можливе економічне та політичне зростання країни, поки в ній немає єдності, перш за все духовно-релігійної? Напевно ні. Тому вирішення проблеми релігійної консолідації населення, єднання навколо єдиного духовного центру та спільної релігійної самоідентифрікації $€$ стратегічно важливими для України. Утворення та становлення нації має відбуватися тільки на українському ґрунті. В центрі об'єднання має стояти все українське, і перш за все це стосується Церкви [6, с. 8].

Релігія здійснює вагомий вплив на формування та збереження національної ідентичності. Комуністичний режим відібрав в українців національні прояви релігії та мову, тобто один із основних маркерів етнорелігійної приналежності, і цим ледь не знищив етнічність українців. Але доки релігія зберігала свою самобутність - етнос вистояв та зберігся [1, с. 630]. Тобто релігія виступає незмінною об'єктивною складовою формування загальнонаціональної ідентичності українських громадян.

Нова цивілізаційна ідентичність, що формується в українському суспільстві, зазнає впливу світових глобалізаційних процесів. Сучасні труднощі $з$ конфесійноцерковним самовизначенням, як складовою майбутньої ідентичності, детермінуються суспільною невизначеністю, що зумовлена низкою суспільно-політичних, соціокультурних проблем, витоки яких вчені відшукують в надрах історії українського народу. На сучасному етапі розвитку етноконфесійна ідентичність зазнає істотних трансформацій, виявлення їх перебігу дасть можливість не лише простежити процес формування нової православної ідентичності, а й передбачити динаміку її розгортання в середовищі православних віруючих.

Провідні вітчизняні науковці визначають тісний взаємозв'язок між етнічністю та релігійністю. Етнічна та релігійна ідентичності часто накладаються та є взаємозалежними. Хоча із історії української держави помітно, що зміна релігійної самоідентифрікації не обов'язково призводила до зміни етнічної ідентичності. В українському суспільстві сьогодні спостерігаємо розмитість та несформованість релігійної та національної ідентичності. Це спонукає наше суспільство до постійного пошуку та формування нової загальної національно-релігійної самоідентифікації [9, с. 223].

Сучасну ситуацію по-іншому можна визначити як криза ідентичності, порівняно з періодом СРСР. В той час орієнтаційний простір обмежувався державно- 
громадськими проблемами. Соціальні утворення виступали центрами тяжіння. Орієнтирами виступали професійна приналежність, партійний статус, радянський народ. Меншу роль відігравали етнічна i, тим більше, релігійна приналежність. Сьогодні особистість постає перед широким колом вибору ідентитів, це значно ускладнює процес самовизначення. 3 одного боку, свобода вибору, а з іншого - труднощі самоідентифікації [10, с. 247].

В Україні, як в інших пострадянських країнах, на фоні несформованості єдиної загальнонаціональної ідентичності, актуальним постає питання пошуку нового спільного для більшості громадян нашої держави орієнтаційного ядра, яке було б центром загальної ідентичності українців. В умовах поліконфесійності та релігійної невизначеності значної частини мешканців України доречним може вважатись загально християнський ідентит "я - християнин".

У одній із найпомітніших наукових розробок $\mathrm{XX}$ ст. теорії про зіткнення цивілізацій С. Гантінгтон відзначав, що кожна із світових цивілізаційних систем має власні особливості, за якими вони власне і різняться. Серед найважливіших характерних категорій мислитель вказує релігію [3, с. 197]. Адже саме вона формує вертикаль людина - Бог, яка для багатьох $€$ визначальною в житті. Кожен по-різному вибудовує цю вертикаль, але саме відношення людини до Бога визначає їі сімейне та повсякденне життя, вибір професії, погляди на політику та державне життя, тощо [4, с. 167].

Сьогодні в Україні спостерігається штучно створена біполярність українського та російського. Це стосується мови, культури, історії та релігії. 3 одного боку, це вводить в оману людей, ламаючи їх історичний код, спільне минуле, родинні зв'язки, а з іншого - погіршує і так загострені стосунки внаслідок протистояння на Сході України. Це в свою чергу призводить до занепаду культури власне української з ії традиціями та звичаями, а також до її поглинання загально радянською (російською), принаймні в Східному регіоні [8, с. 190].

Розглянувши загальну характеристику українського суспільства в цілому, очевидно помітним стає розмежування населення Заходу та Сходу країни. Перш за все цей розподіл криється в релігійній сфері. Релігійна ідентифрікація цих регіонів абсолютно різна. Важливо, що більшість областей Західного регіону позиціонують себе носіями проєвропейського вектору. Це невипадково. Адже значна частина всіх віруючих Львівської, Тернопільської, Івано-Франківської та суміжних областей грекокатолики, які духовно підпорядковані Ватикану [7]. Представники УАПЦ та УКП КП Західного регіону є більш патріотично налаштовані та просякнуті європейським духом і толерантністю [11, с. 167]. Спільні релігійні погляди та настрої формують спільну загальну ідентичність. Людей Західного краю відразу помітно в інших регіонах країни. Вони є стійкими носіями прозахідних поглядів, це накладає помітний відбиток на загальноукраїнське церковне самовизначення. Важливим моментом в цьому аспекті $€$ перенесення духовної столиці УГКЦ із Львова до Києва, зокрема на лівий берег Дніпра. УГКЦ, як і більшість парафрій інших конфессій, постійно позиціонує себе як церква проукраїнська, патріотична і така, що виражає національно-релігійну самоідентифікацію.

Очевидно, що християнство не може не бути місіонерським за своєю суттю. Як світські вчені, так і релігійні ієрархи та богослови свідчать про глибинність конфлікту на релігійному підґрунті. Це криється власне у феномені релігійної віри загалом. Мільйони віруючих намагаються завербувати весь світ, зробити його "своїм". Це рівень підсвідомості. Відтак, релігійні конфлікти - вічні [5, с. 280].

Євангелізація протягом двохтисячолітньої історії християнства виступає одним із прерогативних завдань. Однак, різні церкви християнського напряму по-різному реалізовують цю місію в суспільстві. Це ж стосується і України. Найактивніші в питанні місіонерства традиційно для більшості країн світу $€$ протестантські напрямки та неорелігії. Також активно проповідницькою діяльністю займається УГКЦ. Дещо відстають у цьому питанні Римокатолики, найпасивніші православні. Це відіграє свою значну роль у біполярності України. Західний регіон, де переважає УГКЦ менш піддався впливу протестантських церков, натомість на Сході, де домінує православ'я, яке більш пасивне у плані проповіді неорелігії та протестантські організації створили значно більшу кількість громад.

Євангелізація та місіонерство в Україні тісно переплітаються із прозелітизмом. Останній за своєю суттю вкорінений у саму релігійну ситуацію нашого суспільства. Окремі церкви перебувають у постійному режимі гострої конкуренції. Вони налаштовані на релігійний перерозподіл України. Відтак, перетягування прихожан неминуче. Вся історія українських земель переплітається із масовим прозелітизмом. Ситуація після здобуття Україною незалежності дещо втихла, але продовжує про себе постійно нагадувати численними міжконфесійними суперечками та конфліктами.

Крім того, можна простежити залежність релігійної ідентифікації від рівня національної самосвідомості. Про це свідчить високий рівень релігійної ідентичності етнічних меншин та мешканців Західного регіону. У них рівень етнонаціональної свідомості набагато вищий, відповідно про це свідчать і соціологічні дослідження.

На фоні слабкого, а можливо й відсутнього традиційного релігійного виховання в сім'ї та непомітної місіонерської та просвітницької роботи українських православних церков в Україні, протестантські, неопротестантські та різні новітні релігійні напрями та рухи активно проповідують своє вчення. Це призводить до суперечливого стану релігійної самосвідомості українських громадян. Наприклад, людина може вважати себе віруючою, інколи ходити в православний храм, але паралельно вдаватися до певних окультивних дій, вірити в забобони, астрологію, або ж відвідувати культові споруди інших конфесій [10, с. 256].

Незважаючи на низку очевидних позитивних моментів, релігійна свобода після 1991 р. принесла кілька серйозних непорозумінь та проблем. Одна із них - це питання конфесійної самоідентифрікації прихожан УГКЦ. Здобуття Україною незалежності дало змогу відродитися цій релігійній структурі в галицьких областях. Псевдособор 1946 р. створив штучну резервацію прихожанам цієї церкви. Майже півстолітня заборона призвела до актуалізації питання ідентичності, особливо молодшого покоління галичан. Постало питання, ким вони є: відгалуженням поляків, русинами, в широкому розумінні, чи власне особливим етнорелігійним утворенням. Сьогодні одностайної відповіді ієрархів, вчених і самих вірян не існує. Важливо інше, УГКЦ в процесі українського націєтворення відіграла одну із ключових ролей і сьогодні займає домінуючі позиції в світоглядних орієнтирах мешканців західних областей. Про пошуки власної ідентичності представниками УГКЦ свідчить заява очільника цієї церкви блаженнішого Любомира Гузара, який зауважує, що велика кількість прихожан не може 
самовизначитися. Проблема чи співвідносити себе із православними чи з католиками, чи власне залишитися відокремленою унійною церквою. Серйозна дискусія виникала і між представниками різних груп: катокомбниками та тими хто переходив із православної церкви, а також між новорукополежим духовенством та тими, хто пережив репресії або повернувся з-за кордону.

Варто визнати, що проблема "православної" чи "греко-католицької" ідентичності на Заході залишається відкритою. Незважаючи на наявність значної кількості робочих гіпотез різних вчених не вдається дійти спільного знаменника. На результат впливають численні фрактори впливу: історична пам'ять, етнонаціональна самоідентичність, "радянський відбиток", євроінтеграція, тощо.

Отже, крім православної варто виокремити і грекокатолицьку ідентичність, яка відіграє власну роль та має свою складову у формуванні загальної релігійної ідентичності в Україні. Від "корінних русичів" УГКЦ відрізняється віровизначенням, а від повної полонізації ії вирізняє східний обряд [5, с. 331].

Визначальною сьогодні $€$ спільна історична пам'ять, батьківщина, територія. Визнання цього фактору як основного маркера української ідентичності навіть формально не підважують релігійні організації, представлені в Україні. Різниця між проукраїнськими (наприклад УПЦ КП, УАПЦ, УГКЦ, а також рідновіри) церквами та проросійськими полягає в наступному: проукраїнські роблять акцент на всьому національному, звичаях, древніх традиціях, мові богослужіння тощо; проросійська УПЦ Московського патріархату також прямо не відмовляться від історичних коренів витоків руського православ'я саме з Києва, але постійно нав'язує власне бачення подальшого розвитку "Великої русі", трансформуючи це в ідею "руського міра".

У свою чергу діяльність різновекторних конфесій $€$ неоднозначною щодо реалізації української ідентичності як спільної основи для єдності всіх мешканців України. Відмітимо, що крім незначних власне українських релігійних утворень автентичного походження, які не мають позаукраїнського історичного коріння, решта релігійних організацій - тією чи іншою мірою пов'язані або ж прямо залежні від іноземних релігійних центрів.

Сьогодні ситуація складається таким чином, що в процесі формування національна та релігійна ідентичність українців серйозно піддається впливу різних конфесій. Очевидно, що найбільше на цей процес впливають саме православні церкви, УГКЦ та протестанти. Причому вплив цих церков на соціум $€$ не лише прямий, тобто на конкретних віруючих, прихожан зазначених організацій, а й опосередковано на все суспільство. Цей вплив реалізується релігійно-культурним переданням та всіма тими релігійними перипетіями, що постійно відбуваються в нашому суспільстві. Кожен із нас опосередковано стає їх учасником.

В контексті протистояння Сходу та Заходу, негативну роль відіграє Московська церква та особисто її очільник патріарх Кирило. Його пропаганда домінування Сходу в духовному відношенні переважно налаштована не на проукраїнські церкви, і навіть не на західнохристиянські конфесії, а на "безбожний Захід" в цілому. Критикується споживацька євроатлантична цивілізація. Разом із тим, не можна зводити різницю між цими двома регіонами виключно в релігійну сферу. Сама історія українських земель складалась так, що Західний регіон завжди підпорядковувався проєвропейським (католицько-протестантським) країнам, наприклад Австро-
Угорська імперія, Річ Посполита. А Схід - до Російської імперії, переважно православної. Причому, історія наводить приклади численних воєнних протистоять між згаданими державами.

Сюди ж доречно віднести й мовне питання. Протиріччя при використанні української та російської зводять до регіоналізації, що ставить вирішення даного питання у глухий кут. Повністю уніфікувати українське суспільство неможливо, та і не потрібно. Кожен із регіонів країни $є$ унікальним та історично сформованим, а досягнути консенсусу в мовному питанні цілком можливо [8, с. 211]. Подібне має спостерігатися і в українській освіті, як шкільній, так і вищій. Вона не повинна орієнтуватися чи то на Захід, чи на Схід. Неважливо буде Болонський процес чи якийсь інший. Головне, що в її основі лежала національна ідея. Важливо щоб своїм завданням українська освіта ставила виховання спільної національної ідентичності, в тому числі на основі загальнохристиянських норм і спільного вчення. Можливо доречно із православних нахилом.

Ще одним важливим об'єднуючим фрактором, який впливає на формування спільної ідентичності, в тому числі і релігійної Е. Сміт називає колективним. Тобто це люди, які проживають спільно, мають спільну історію, та пов'язані із спільною територією та простором. Вчений вказує на переваги релігійної та етнічної ідентичності в порівнянні із класовою. Це пов'язано з релігійною ідентичністю, що може включати кілька класів, тобто $€$ ширшою за обсягом. А базується вона на єдності культури та певних спільних елементах (символи, обряди, міфи, звичаї) [12, с. 46]. Таким чином, сукупність вищенаведених принципів впливає на формування окремої релігійної ідентичності Західного регіону.

Натомість не спостерігається проникнення Східного регіону в духовному плані на Захід чи хоча б в Центр країни. Апріорі схід проросійсько налаштований, вирізняється великим відсотком невіруючого населення або ж віруючого лише номінально. Відтак, такі "вірячи" не $€$ повноцінним носіями своєї релігії та виразниками власної релігійної ідентифікації толерантністю [4, с. 167].

Церковно-релігійна парадигма Сходу - Московський патріархам. Саме там набувають потужного поширення ідеї "Третього Риму", "Руського міра" і подібне. Проте для більшості українців це неприйнятні парадигми,відтак жителі Сходу хоча і мають власну релігійнодержавницьку ідентичність, не спроможні розповсюджувати їі Україною.

Не можна не відмітити і той фракт, що Московський патріархат, представлений в Україні у вигляді УПЦ МП, сподівається, що представники "руської" (радянської) ідентичності репрезентуватимуть виключно православ'я. Не секрет, що серед всієї кількості віруючих РПЦ більше третини становлять вірячи саме УПЦ МП. Відтак, Москва всіляким чином пропагує власну релігійну ідентичність населенню Східного та Південного регіонів України [2, с. 246]. Зокрема, нинішній очільник цієї церкви патріарх Кирило неодноразово заявляв, що Київ $є$ для РПЦ другим Єрусалимом, духовною колискою, відтак ніхто ним поступатися не збирається. Навпаки, під час своїх візитів до різних єпархій України до подій 2013 р. заявляв про потенційне збільшення і утвердження у вірі пастви саме з України. Патріарх невпинно наголошував на ідеї "руського міра". Разом із тим, далеко не все населення і до, а тим паче, після революційних післямайданівських подій приймало його позицію. Важливо, що українці і на Сході країни все ж виріз- 
няються власною релігійною ідентичністю і виступають прихильниками створення Єдиної Помісної Церкви.

Потужно впливають на формування спільної національно-релігійної ідентичності спільні традиції, міфи та звичаї. Попри існування значної кількості регіональних особливостей та місцевих вставок, існує традиційний всеукраїнський список таких обрядів, навіть якщо вони й представлені в різних варіаціях. Частина звичаїв у трансформованому вигляді дійшли до нас ще з дохристиянської доби. Звісно, вони давно обросли певними конфесійними нашаруваннями. Перш за все традиції та звичаї торкаються основних моментів людського життя: народження, одруження, смерть, а також найбільших календарних церковних свят.

Реалії сучасної поліконфесійності в Україні накладають значний відбиток на формуванні загальної релігійної ідентичності її мешканців. Розкол православ'я на різні юрисдикції продовжує негативно впливати на формування біполярної релігійної свідомості наших співвітчизників. Українське перехідне суспільство не може наразі згуртуватися навколо однієї загальнонаціональної ідеї. Відтак і відсутня єдина національна ідентичність. В свою чергу релігія $€$ базовою основою для їі формування. Православна віра історично невід'ємна від мешканців українських земель. Релігійний фрактор не можна не враховувати при розгляді фундаментальних загальнонаціональних проблем України. А формування єдиної національно-релігійної ідентифікації українців $є$ одним із ключових для нашої держави. Тому державні та церковній варто прикласти максимум зусиль для позитивного вирішення питання єдиної релігійної ідентичності в Україні.

\section{Список використаних джерел:}

1. Академічне релігієзнавство: Підручник / за ред. А. Колодного. К. : Світ Знань, 2000. - 862 с.

2. Вергелес К. Проблеми національного буття Російської православної церкви / К. Вергелес // Історія релігій в Україні : науковий щорі- чник / упоряд. О. Киричук, М. Омельчук, І. Орлевич. - Л. : Інститут релігієзнавства; Вид-во "Логос", 2014. - Книга ІІ. - С. 244-253.

3. Гантінгтон С. Протистояння цивілізацій та зміна світового порядку / С. Гантінгтон; [пер. з англ. Наталії Климончук]. - Л.: Кальварія, 2006. $-474 \mathrm{C}$

4. Гаюн В. Дубров Я. Зіткнення на перехресті розлому двох релігійних цивілізацій в Україні: 2013р. // Історія релігій в Україні : науковий щорічник / упоряд. О. Киричук, М. Омельчук, І. Орлевич. - Л. : Інститут релігієзнавства; Вид-во "Логос", 2014. - Книга ІІ. - С. 157 - 172

5. Єленський В. Релігія після комунізму. Релігійно-соціальні зміни в процесі трансформації центрально- і східноєвропейських суспільств: фокус на Україні / В. Є. Єленський. - К. : НПУ ім. М. П. Драгоманова, 2002. -420 c.

6. Жилюк С. Без апологетики. Витоки оновлення православної церкви в Україні / С. І. Жилюк. - Житомир: Полісся, 2000. - 164 с.

7. Звіт про мережу церков і релігійних організацій в Україні станом на 01.01.2018 року [Електронний ресурс]. - 2016. - Режим доступу: https://risu.org.ua/ua/index/resourses/statistics/ukr_2018/70440/

8. Козловець М., Ковтун Н. Національна ідентичність в Україні в умовах глобалізації : монографрія / М. Козловець, Н. Ковтун. - К. ПАРАПАН, 2010. - 348 с.

9. Маринович М. Проблема збереження релігійної ідентичності в умовах відкритого суспільства / М. Маринович // Громадянське суспільство як здійснення свободи: центрально-східноєвропейський досвід / За заг. ред. А. Карася. - Л., 1999. - С. 219-224.

10. Ніколаєвська А. М. Релігійна ідентичність в системі соціальних ідентичностей українського студентства / А. М. Ніколаєвська // Науковий блог Національного університету "Острозька академія". - С. 245-249.

11. РЕЛІГІЯ - СВІТ - УКРАЇНА. Колективна монографія в 3-х книгах за науковою редакцією професорів А. Колодного і Л. Филипович. Книга III: Релігійні процеси в перспективі їх виявів // Українське релігієзнавство. - К., 2012. - № 61. - 550 с.

12. Сміт Е. Національна ідентичність / Сміт Ентоні Д. [Пер. з англ. П. Таращука]. - К. : Основи, 1994. - 224 с.

13. Шевченко В. В. Православно-католицькі взаємини в проблематичному розрізі ідентифікаційних вимірів сучасності (український контекст) / В.В. Шевченко // Україна і Ватикан в контексті культурноцивілізаційного діалогу: історія і сучасність. - К., 2009. - С. 90-98

Надійшла до редколегії 06.02.19

\section{В. М. Калач}

\section{РЕЛИГИОЗНАЯ ИДЕНТИЧНОСТЬ}

\section{В КОНТЕКСТЕ ЭТНОНАЦИОНАЛЬНОГО РАЗВИТИЯ УКРАИНЫ}

В статье рассматриваются особенности формирования религиозной идентичности в динамике геополитических процессов в Украине, которые зависят от исторических условий, особенностей экономического и социально-политического устройства, демократических и культурных традиций общества, уровня правового и нравственного развития его членов и амбиций ее лидеров. Доказано, что религия является решающим фактором этнического бытия украинцев, отмечена противоречивая роль христианства в этноидентификационных и этноконсолидационных процессах.

Ключевые слова: религиозная идентичность, самоидентификация, межрелигиозные отношения, этнонациональное сознание.

V. M. Kalach

\section{RELIGIOUS IDENTITY IN THE CONTEXT}

\section{OF THE ETHNO-NATIONAL DEVELOPMENT OF UKRAINE}

The article discusses the peculiarities of the formation of religious identity in the dynamics of geopolitical processes in Ukraine, which depend on historical conditions, features of the economic and socio-political structure, democratic and cultural traditions of society, the level of legal and moral development of its members and the ambitions of its leaders. It is proved that religion is a decisive factor in the ethnic life of Ukrainians, and the controversial role of Christianity in ethno-identification and ethno-consolidation processes is noted.

The modern world-wide political, economic and spiritual crisis imposes its imprint on Ukraine as well. As one of the transitional countries of the post-socialist space, our state has not yet found a single-minded vector of its own development, in particular, the ecclesiastical. Ukraine is only on the verge of forming a united national idea and crystallizing its own self-identification on the religious marker.

Religion is the basic semantic-forming component of a unified national identity. Today, religious and ethnic identities are closely intertwined. Therefore, the problem of the ethnorelain factor always attracts significant attention of leading scholars, statesmen and church hierarchs. In Ukraine, a significant number of religious groups completely coincide with the boundaries of a separate ethnic group.

The lack of civic consensus on the country's foreign policy, cultural identity, separate sovereign positions of the Ukrainian state, the diverse views of the past and the future at the present makes it impossible to formulate unanimous interests, which negatively affects external and internal policies.

Compared with the Soviet period, religious identity today is a relatively new category. On opposition to the state-civilian benchmark for many Ukrainians, religion is on the forefront. Undeniably, Orthodoxy played a very important role in the formation of the Ukrainian nation and our religious identity. However, today, multiconfessional diversity and inability or reluctance to negotiate, to be tolerant, break Ukraine into several regions. The negative tendency of loss of awareness of Ukrainians of the unity of religion, nation, common spirit is traced.

The formation of religious identity is a long process of formation of society as a whole, and is a consequence of the historical formation of Ukraine as a nation. Religious identification is the reproduction of accumulated social and religious experience in all spheres. World and domestic scholars are unequivocal in the conclusions that the central place in the formation of national identity belongs to religiousness. Religious beliefs that have an indelible imprint of an ethnic group living on a particular territory are precisely the center of the formation of a new national-religious identity of Ukrainian society.

Key words: religious identity, self-identification, interfaith relations, ethno-national consciousness. 